\title{
The Influence of Self Management Dietary Counseling on The Value of Sodium and Edema in Hemodialysis Patients
}

\author{
Faradisa Yuanita Fahmi ${ }^{1}$, Titik Hidayati², Nur Chayati ${ }^{3}$ \\ ${ }^{1}$ Health Science Institute of Muhammadiyah Kendal \\ 2,3 University of Muhammadiyah Yogyakarta
}

\section{Article Info}

Article History:
Accepted February 13rd
2019

Key words:

SMDC; Hemodialisa;

Sodium; Edema

\begin{abstract}
Background: Reducing salt care \& reducing fluid intake is one of the efforts to prevent fluid imbalance in patients. The increase in the prevalence of events that occur in hemodialysis patients is caused by various factors, one of which is inaccuracy in doing therapy. Self Management Dietary Counseling (SMDC) aims to increase patient knowledge and participate in health decision making to improve patient compliance and clinic outcome. Purposes : Knowing the effect of Self Management Dietary Counseling (SMDC) on the value of sodium in hemodialysis patients. Methode : Quasy Experiment, prestest - post test design, 60 samples consisted of 3 groups. Sampling using random sampling technique. Result : the group treated with SMDC has a $\mathrm{p}$ value $<0.050$, while the non-treated group has a $\mathrm{p}$ value> 0, 050. Conclusion : Self Management Dietary Counseling has an effect on the value of sodium in hemodialysis patients. This study recommends that nurses apply SMDC to each hemodialysis patient to improve the value of sodium.
\end{abstract}

\section{PENDAHULUAN}

Ginjal merupakan organ penting dalam hidup manusia yang berfungsi sebagai pengatur volume dan komposisi kimia darah dengan mengeksresikan solut dan air secara selektif. Sistem eksresi yang terganggu menyebabkan menumpuknya zat - zat toksik dalam tubuh yang kemudian menyebabkan sindrom uremi. Ginjal juga berfungsi untuk mengatur konsentrasi garam dalam darah, dan keseimbangan asam basa darah serta eksresi bahan buangan dan kelebihan garam (Costa, E., Rocha, S., Pereira, P.R, Castro, E, Reis, F., Miranda, V., Faira M.D.S., Loureiro, A and Silva, 2008). ; (Evelyn C.Pearce, 2008).
Gangguan pada ginjal bisa terjadi karena sebab primer ataupun sebab sekunder dari penyakit lain. Ginjal apabila gagal menjalankan fungsinya, maka penderita memerlukan pengobatan dengan segera. Keadaan dimana ginjal lamban laun mulai tidak dapat melakukan fungsi dengan baik disebut dengan gagal ginjal (Lajuck, Moeis, \& Wongkar, 2016). ; (Brunner, 2010).

Hemodialisis merupakan salah satu terapi pengganti ginjal yang bertujuan untuk memperbaiki komposisi cairan sehingga mencapai keseimbangan cairan yang diharapkan untuk mencegah kekurangan atau kelebihan cairan yang dapat menyebabkan efek yang signifikan terhadap komplikasi kardiovaskuler dalam jangka

\footnotetext{
Corresponding author:

Faradisa Yuanita Fahmi yuanita0fara@gmail.com Media Keperawatan Indonesia, Vol 2 No 1, February 2019 
panjang. Terapi hemodialisa bekerja untuk memisahkan sampah dan produk metabolik esensial (sampah nitrogen dan sampah lain) melalui selaput membrane semi permiabel (Sari, 2018).

Hemodialisis masih menjadi masalah besar di dunia. Selain sulit disembuhkan, biaya perawatan dan pengobatannya sangat mahal. Hemodialisis di Indonesia mulai tahun 1970 dan sampai sekarang telah dapat dilaksanakan di banyak rumah sakit rujukan. Kualitas hidup yang diperoleh cukup baik dan panjang umur yang tertinggi sampai sekarang sampai 14 tahun. Indonesia termasuk negara dengan tingkat penderita gagal ginjal yang cukup tinggi .

Pengurangan asupan garam \& pengurangan intake cairan merupakan salah satu upaya untuk mencegah terjadinya ketidakseimbangan cairan pada pasien hemodialisa. Garam merupakan senyawa yang terdiri dari ion natrium \& klorida. Natrium merupakan kation terbanyak dalam cairan ekstra sel, jumlahnya bisa mencapai $60 \mathrm{mmol}$ per $\mathrm{kg}$ berat badan dan sebagian kecil (sekitar $10-14 \mathrm{mmol} / \mathrm{L}$ ) berada dalam cairan intrasel. Dalam keadaan normal eksresi natrium pada ginjal diatur sehingga keseimbangan dipertahankan antara asupan dan pengeluaran dengan volume cairan ekstra sel tetap stabil. Lebih dari $90 \%$ tekanan osmotik di cairan ekstrasel ditentukan oleh garam, khususnya dalam bentuk natrium klorida $(\mathrm{NaCl})$ dan natrium bikarbonat (NaHCO3) sehingga perubahan tekanan osmotik pada cairan ekstrasel menggambarkan perubahan konsentrasi natrium (Wulan \& Emaliyawati, 2018).

Perbedaan kadar natrium dalam cairan ekstrasel dan intrasel disebabkan oleh adanya transpor aktif dari natrium keluar sel yang bertukar dengan masuknya kalium ke dalam sel (pompa Na K) Jumlah natrium dalam tubuh merupakan gambaran keseimbangan antara natrium yang masuk dan natrium yang dikeluarkan. Kadar natrium normal dalam tubuh ialah 135-145
mmol/L. Pemasukan natrium yang berasal dari diet melalui epitel mukosa saluran cerna dengan proses difusi dan pengeluarannya melalui ginjal, saluran cerna atau keringat di kulit (Wulan \& Emaliyawati, 2018).

Jumlah pasien yang menjalani hemodialisis di RSUD dr. Moewardi mengalami peningkatan tiap tahunnya. Berdasarkan catatan rekam medik tercatat pada tahun 2012 bulan November - Desember sebesar 324 pasien, tahun 2013 sebesar 25.262 pasien, tahun 2014 sampai dengan Mei 2015 sebanyak 25.520 orang. Jumlah tersebut yang secara rutin menjalani hemodialisis sejumlah 228 (Rekam Medik RSUD dr. Moewardi, 2015). Peningkatan prevalensi kejadian yang terjadi pada pasien hemodialisa disebabkan oleh berbagai faktor salah satunya ketidaktepatan dalam melakukan terapi. Hal ini dibuktikan dengan wawancara dengan perawat RSUD dr. Moewardi yang mana didapatkan bahwa kebanyakan pasien kurang termotivasi dalam menjalani diit cairan. Hal ini dibuktikan dengan adanya ketidakseimbangan natrium \& terjadinya edema.

(López-Gómez, Villaverde, Jofre, RodriguezBenítez, \& Pérez-García, 2005). menyatakan bahwa asupan makanan juga akan menyebabkan kelebihan natrium dan air dan memberikan kontribusi untuk IDWG (Interdialytic weight gain) . Asupan yang terlalu bebas dapat mengakibatkan beban sirkulasi yang berlebihan, edema dan intoksikasi air. Banyak juga penumpukan cairan terjadi di rongga perut yang membuat perut membuncit dan disebut asites. Kondisi ini akan membuat tekanan darah meningkat dan memperberat kerja jantung (Potter, P. A., Perry, A. G., Stockert, P., \& Hall, 2016).

Berdasarkan fenomena rendahnya motivasi pasien dalam melakukan diit cairan, maka dibuatlah suatu inovasi untuk mengembangkan kepatuhan menjadi bentuk kemandirian terhadap pengelolaan 
diit terutama pada pasien gagal ginjal kronik. Inovasi tersebut berdasarkan suatu model behavior dalam bentuk framework yang berfokus pada self efficacy (Karavetian, M., \& Ghaddar, 2012).

Self Management dengan metode SMDC (Self Management Dietary Counseling) merupakan intervensi yang digunakan sebagai terapi pendekatan behavior kognitive. Hasil penelitian (Karavetian, M., \& Ghaddar, 2012). yang dilakukan di Lebanon pada pasien hemodialisis, menunjukkan perubahan yang signifikan pada peningkatan pengetahuan, kepatuhan serta nilai biochemical clinic. Penelitian menurut (Kurniasih, 2014). menunjukkan dengan diberikannya konseling dapat meningkatkan pengetahuan dan kesehatan mental. Konseling dapat memperbaiki kualitas hidup pada pasien gagal ginjal kronik sehingga dapat sebagai model merawat pasien gagal ginjal kronik.

Fenomena tingginya prevalensi kejadian pasien yang menjalani hemodialisa dan rendahnya kepatuhan pasien dalam menjalani diit cairan, membuat peneliti tertarik untuk melakukan penelitian di RSUD dr. Moewardi Surakarta. Alasan selain tingginya prevalensi kejadian HD dan rendahnya kepatuhan tersebut adalah, bahwa RS tersebut sudah terakreditasi A sehingga secara kualitas pelayanan lebih terstruktur di semua bagian.

\section{METODE PENELITIAN}

Jenis penelitian yang digunakan adalah Quasi eksperimen dengan pretest dan post test with control group. Rancangan penelitian ini bertujuan untuk mengetahui pengaruh SMDC terhadap nilai natrium \& kejadian edema pada pasien hemodialisa. Responden dibagi menjadi 3 kelompok, yaitu satu kelompok kontrol dan dua kelompok intervensi. Kelompok intervensi yang pertama diberikan konseling $1 \mathrm{x}$ dalam 1 minggu, sedangkan kelompok intervensi kedua diberikan konseling $2 \mathrm{x}$ dalam 1 minggu. Kelompok intervensi diobservasi terlebih dahulu sebelum dilakukan intervensi, kemuadian diobservasi setelah dilakukan intervensi sedangkan kelompok kontrol diobservasi tanpa dilakukan intervensi.

Waktu penelitian dilakukan 5 minggu dimulai 16 Mei sampai 18 Juni. Pemilihan responden berdasarkan kriteria inklusi \& Ekslusi serta pemberian informed concent dilakukan pada minggu pertama. Evaluasi dilakukan pada minggu ke 5. Durasi pemberian konseling selama $30-60$ menit.

Populasi dalam penelitian ini adalah seluruh pasien yang menjalani hemodialisis di RS dr. Moewardi Surakarta pada tahun 2015, yaitu sebanyak 228 pasien. Jumlah sampel dalam penelitian ini didapatkan sebanyak 20 pada setiap kelompok, sehingga jumlah keseluruhan sampel untuk ketiga kelompok sebanyak 60. Penelitian ini menambahkan $10 \%$ dari total sampel untuk menghindari kemungkinan terjadinya drop out selama penelitian sehingga didapatkan sampel sebanyak 66 responden (Dharma, 2011).

\section{HASIL}

Tabel 1

Distribusi frekuensi karakteristik responden yang menjalani hemodialisis di RSUD Dr. Moewardi Surakarta Bulan Mei - Juni $2016(\mathrm{n}=60)$

\begin{tabular}{|c|c|c|c|c|}
\hline \multirow[b]{2}{*}{ Indikator } & \multicolumn{3}{|c|}{ Kelompok $(n=60)$} & \multirow[b]{2}{*}{$\begin{array}{c}\text { Total } \\
(\%)\end{array}$} \\
\hline & $\begin{array}{c}\mathrm{I} \\
\Sigma(\%)\end{array}$ & $\begin{array}{c}\text { II } \\
\Sigma(\%)\end{array}$ & $\begin{array}{c}\text { III } \\
\Sigma(\%)\end{array}$ & \\
\hline \multicolumn{5}{|l|}{ Jenis Kelamin } \\
\hline a. Laki - Laki & $10(50)$ & $15(75)$ & $12(60)$ & $37(61,7)$ \\
\hline b. Perempuan & $10(50)$ & $5(25)$ & $8(23)$ & $23(38,3)$ \\
\hline \multicolumn{5}{|l|}{ Pendidikan } \\
\hline a. SMP & $5(25)$ & $8(40)$ & $7(35)$ & $20(33,3)$ \\
\hline b. SMA & $11(55)$ & $9(45)$ & $11(55)$ & $31(51,7)$ \\
\hline c. PT & $4(20)$ & $3(15)$ & $2(10)$ & $9(15)$ \\
\hline \multicolumn{5}{|l|}{ Umur (tahun) } \\
\hline a. $21-30$ & $1(1,6)$ & $0(0)$ & $0(0)$ & $1(1,7)$ \\
\hline b. $31-40$ & $5(8,3)$ & $10(16,7)$ & $7(11,7)$ & $22(36,7)$ \\
\hline c. $41-50$ & $8(13,3)$ & $3(5)$ & $6(10)$ & $17(28,3)$ \\
\hline d. $51-60$ & $6(10)$ & $7(11,6)$ & $7(11,7)$ & $20(33,3)$ \\
\hline \multicolumn{5}{|l|}{ Penghasilan Klg } \\
\hline a. $\geq 1$ juta & $8(40)$ & $7(35)$ & $7(35)$ & $23(38,3)$ \\
\hline b. $<1$ juta & $12(60)$ & $13(65)$ & $13(35)$ & $37(61,7)$ \\
\hline
\end{tabular}


Berdasarkan tabel 1 tentang distribusi frekuensi berdasarkan karakteristik responden yang menjalani hemodialisis, didapatkan hasil bahwa jenis kelamin responden didominasi oleh laki - laki yaitu sejumlah $61,7 \%$, tingkat pendidikan responden didominasi SMA sejumah 51,7\%, umur responden didominasi pada rentang usia 31 - 40 tahun yaitu sejumlah 36,7\%, sedangkan penghasilan keluarga di dominasi oleh jumlah penghasilan $<1$ juta yaitu 37 61,7\%.

Tabel 2

Frekuensi dan homogenitas berdasarkan nilai laboratorium dan parameter biologi pada pasien hemodialisa di RSUD dr. Moewardi Surakarta Bulan

\begin{tabular}{llll}
\multicolumn{3}{c}{ Mei - Juni $2016(\mathrm{n}=60)$} \\
\hline Parameter & Minimum & \multicolumn{2}{c}{ P VALUE } \\
\cline { 3 - 4 } & $( \pm$ max $)$ & I \& III & II \& III \\
\hline Edema & $0 \pm 4$ & 0,44 & 0,23 \\
Natrium & $135 \pm 147$ & 0,16 & 0,57
\end{tabular}

Berdasarkan tabel 2 tentang frekuensi dan homogenitas berdasarkan parameter biologi dan laboratorium di dapatkan hasil bahwa untuk semua parameter terdistribusi merata pada kelompok I\&III, dan II\&III. Hal ini bearti bahwa data karakteristik pda tabel diatas bersifat homogen.

\section{Tabel 3}

Pengaruh SMDC terhadap nilai natrium \& derajat edema pada pasien yang menjalani hemodialisa di RSUD dr. Moewardi Surakarta Bulan Mei - Juni 2016

\begin{tabular}{cc}
\multicolumn{2}{c}{$(\mathrm{n}=60)$} \\
\hline Kelompok & P VALUE \\
\hline
\end{tabular}

\begin{tabular}{ll}
\hline Edema & \\
a. Kelompok 1 & $0,00^{*}$ \\
b. Kelompok 2 & $0,01^{*}$ \\
c. Kelompok 3 & $0,12^{*}$ \\
\hline
\end{tabular}

\begin{tabular}{ll}
\hline Natrium & \\
a. Kelompok 1 & $0,00^{*}$ \\
b. Kelompok 2 & $0,00^{*}$ \\
c. Kelompok 3 & $0,14^{*}$
\end{tabular}

1 : (intervensi SMDC 1X seminggu), 2 : (Intervensi SMDC 2X seminggu), III : kontrol

*Wilcoxone test

Berdasarkan tabel 3 tentang pengaruh SMDC terhadap nilai natrium \& kejadian edema didapatkan hasil kelompok 1 dan kelompok 2 mempunyai nilai $p$ value $<0,05$ yang bermakna bahwa SMDC memberikan pengaruh signifikan pada nilai natrium \& kejadian edema sedangkan pada kelompok 3 mempunyai nilai $p$ value $>0,05$ yang bermakna bahwa tidak terdapat pengaruh yang signifikan.

\section{PEMBAHASAN}

Hemodialisis merupakan proses pembersihan darah oleh akumulasi sampah buangan. Terapi hemodialisis aman dan bermanfaat untuk dilakukan pada pasien, namun meskipun aman bukan bearti proses terapi hemodialisis ini tidak terdapat efek samping. Komplikasi yang sering terjadi pada pasien adalah terjadinya kelebihan volume cairan pada tubuh. Hal ini disebabkan oleh berbagai faktor (Tovazzi, M. E., \& Mazzoni, 2012)..

Perburukan volume cairan pada pasien hemodialisis dapat dimanifestasikan dengan tidak seimbangnya nilai biochemical marker yang meliputi natrium \& kalium serta kejadian edema. Edema pada penelitian ini terjadi pada beberapa pasien. Hal tersebut disebabkan karena pada pasien GGK, keadaan ginjal sering tidak dapat mengeksresikan natrium yang masuk melalui makanan dengan cepat sehingga natrium akan tertimbun dalam ruang ekstraseluler dan menarik air (Hidayati \& Sitorus, 2009).

Self Management Dietary Counseling dapat membantu memberikan penjelasan yang lebih baik terhadap manifestasi yang diderita. Konseling memberikan peran besar dalam perbaikan nilai natrium. Dengan adanya SMDC responden bisa lebih memahami tindakan apa yang harus dilakukan untuk memperbaiki nilai natrium dan derajat edema. Hal ini sesuai dengan teori bahwa faktor kurangnya pengetahuan pada pasien GGK yang menjalani hemodialisa akan dapat mengakibatkan beberapa perburukan fisik yang meliputi kenaikan berat badan, edema, ronkhi basah, kelopak mata bengkak, ketidakseimbangan 
natrium dan sesak nafas (Smeltzer, S.C \& Bare, 2010).

Berdasarkan hasil penelitian ini diketahui bahwa SMDC (Self Management Dietary Counseling) dapat memberikan pengaruh positif terhadap perbaikan nilai natrium \& perbaikan derajad edema pada pasien hemodialisa. Hal ini dibuktikan dengan nilai ( $p$ value) $<0,050$ pada kelompok perlakuan (kelompok $1 \&$ kelompok 2).

Perbaikan nilai natrium pada responden pada penelitian ini, dikarenakan sebelumnya responden tidak memahami akan terapi yang tepat. Mereka hanya mengurangi asupan cairan tanpa diukur sesuai dengan batas yang ditetapkan yaitu 500 cc ditambah jumlah urine yang keluar (Istanti, 2011).. Kegiatan untuk mengurangi rasa asin, MSG \& pedas sebagian besar sudah mampu mereka lakukan dirumah, namun ketika membeli makanan diluar mereka mengikuti makanan yang telah tersaji tanpa mengetahui seberapa banyak garam ataupun MSG yang dimasukkan ke dalam makanan tersebut. Pasien hemodialisis pemberian natrium harus dilakukan pada tahap yang ditolerir dengan tujuan untuk mempertahankan volume ekstraseluler karena pada pasien gagal ginjal kronik, natrium dipertahankan didalam tubuh walaupun faal ginjal menurun (Potter, P. A., Perry, A. G., Stockert, P., \& Hall, 2011). ; (Lindberg, 2010). menyatakan pasien dengan gangguan fungsi ginjal kronis juga dapat mengalami edema akibat retensi garam \& air.

Perilaku responden yang tidak terkontrol akan asupan garam \& MSG membawa dampak buruk pada pasien bahwasanya asupan tersebut dapat merangsang rasa haus yang berlebihan. Merespon rasa haus normalnya dengan minum, tetapi pada pasien ini, tidak diijinkan untuk berespon dengan cara normal terhadap rasa haus yang mereka rasakan (Istanti, 2014).. Perilaku ketidakpatuhan tersebut dipengaruhi oleh berbagai faktor diantaranya adalah faktor usia. terlihat pada penelitian ini, responden didominasi oleh rentang usia 31 - 40 tahun $(36,7 \%)$ yang menunjukkan bahwa usia tersebut seseorang mempunyai peran yang banyak. Individu mulai membagi waktunya dengan kelompok sosial mereka. Seseorang ketika mengalami penyakit kronik, mereka akan terdapat konflik sehingga beresiko akan menjadi tidak patuh dan menyebabkan rendahnya kemampuan self care (Saran, R., Bragg-Gresham, J. L., Rayner, H. C., Goodkin, D. A., Keen, M. L., Van Dijk, P. C., ... \& Young, 2003)..

\section{SIMPULAN}

Berdasarkan hasil analisa yang telah dilakukan dapat ditarik kesimpulan bahwa Self Management Dietary Counseling memberikan pengaruh terhadap perbaikan nilai natrium \& derajat edema

\section{REFERENSI}

Brunner, L. \& S. (2010). Textbook of medical. medical surgical nursing (vol.1) (Lippincott).

Costa, E., Rocha, S., Pereira, P.R, Castro, E, Reis, F., Miranda, V., Faira M.D.S., Loureiro, A and Silva, A. (2008). Cross-talk Beetwen Inflamation, Coagulation/Fibrinolysis and Vascular Acces in Hemodialysis Patients. ', 9; 248-2.

Dharma, K. K. (2011). Metodologi penelitian keperawatan: panduan melaksanakan dan menerapkan hasil penelitian (Jakarta: T).

Evelyn C.Pearce. (2008). . Anatomi dan fisiologi untuk para medis. ( jakarta P. Gramedia, Ed.).

Hidayati, S., \& Sitorus, R. (2009). Efektivitas Konseling Analisis Transaksional Tentang Diet Cairan Terhadap Penurunan Interdialytic Weight Gain ( Idwg ). Prosiding Seminar Nasional Dan Internasional Unimus.

Istanti. (2011). Faktor - faktor yang berkontribusi terhadap interdyalitic weight gains pada pasien Chonic Kidney Disease yang menjalani hemodialisa. Jurnal Article. Mutiara Medika.

Istanti. (2014). Hubungan Antara Masukan Cairan Dengan Interdyalitic Weight Gain (IDWG) pada Pasien Chronic Kidney Disease di Unit

Faradisa Yuanita Fahmi / The Influence of Self Management Dietary Counseling on The Value of Sodium and Edema in Hemodialysis Patients 
Hemodialisis RS PKU Muhammadiyah Yogyakarta.

Karavetian, M., \& Ghaddar, S. (2012). Nutritional education for the management of osteodystrophy (nemo) in patients on haemodialysis: a randomised controlled trial. Journal of Renal Care, 39(1), 19-30.

Kurniasih, S. (2014). Evaluasi Pengaruh Pemberian Konseling dan short messages service (SMS) terhadap kepatuhan terapi hipertensi pasien hemodialisis di RSUD Banjar.

Lajuck, K. S., Moeis, E. B., \& Wongkar, M. C. P. (2016). Status Gizi pada Pasien Penyakit Ginjal Kronik Stadium 5 yang Menjalani Hemodialisis Adekuat dan Tidak Adekuat. Jurnal E-Clinic, $4(2), 0-5$.

Lindberg. (2010). Exercise fluid overload among haemodialysis. UPSALA UNIVERSITET.

López-Gómez, J. M., Villaverde, M., Jofre, R., Rodriguez-Benítez, P., \& Pérez-García, R. (2005). Interdialytic weight gain as a marker of blood pressure, nutrition, and survival in hemodialysis patients. Kidney International, 67, S63-S68. https://doi.org/10.1111/j.15231755.2005.09314.x

Potter, P. A., Perry, A. G., Stockert, P., \& Hall, A.
(2011). Fundamentals of Nursing-E-Book (Elsevier $\mathrm{H}$ ).

Potter, P. A., Perry, A. G., Stockert, P., \& Hall, A. (2016). Fundamental of Nursing E-Book (Elsevier $\mathrm{H}$ ).

Saran, R., Bragg-Gresham, J. L., Rayner, H. C., Goodkin, D. A., Keen, M. L., Van Dijk, P. C., ... \& Young, E. W. (2003). Nonadherence in hemodialysis: associations with mortality, hospitalization, and practice patterns in the DOPPS. Kidney international, 64(1, 254-262.

Sari, L. . (2018). Pengaruh Mesenchymal Stem Cell Terhadap Kadar Kreatinin Pada Tikus Gagagl Ginjal Akut- Studi invivo pada tikus putih jantan Galur Wistar yang diinduksi gentamisin. Doctoral Disertation UNISULLA.

Smeltzer , S.C \& Bare, B. . (2010). Buku ajar keperawatan medikal bedah.

Tovazzi, M. E., \& Mazzoni, V. (2012). Personal paths of fluid restriction in patients on hemodialysis. Nephrology Nursing Journal, 207.

Wulan, S. N., \& Emaliyawati, E. (2018). Kepatuhan Pembatasan Cairan dan Diet Rendah Garam ( Natrium ) pada Pasien GGK yang Menjalani Hemodialisa; Perspektif Health Belief Model, 5(3), 99-106. 